УДК 94 (571.651). 8

\title{
КОЛЛЕКТИВИЗАЦИЯ ВИЛЮНЕЙСКИХ ЧУКЧЕЙ: ПРИЧИНЫ И ХОД ПРОТИВОСТОЯНИЯ
}

\author{
Хаховская Л. Н. \\ ФГБУН Северо-Восточный комплексный научно-исследовательский институт \\ им. Н. А. Шило ДВО РАН, г. Магадан \\ E-mail:hahovskaya@gmail.com
}

\begin{abstract}
Автор анализирует процесс коллективизации локальной группы вилюнейских чукчей. Чукчиоленеводы оказывали вооруженное сопротивление советским преобразованиям. Большой резонанс имеет центральное событие коллективизации вилюнейцев, известное как восстание в селе Берёзово. Автор прослеживает историческую, социальную и этнокультурную подоплеку длительного противостояния вилюнейских чукчей советской власти. Сделан вывод, что во время коллективизации вилюнейские чукчи руководствовались теми стереотипами межэтнических взаимодействий, которые сложились в предшествующую историческую эпоху.
\end{abstract}

Ключевые слова: чукчи, вилюнейская тундра, оленеводы, коллективизация, этносоциальный конфликт, этническая история, село Берёзово, вооруженная борьба.

DOI: $10.34078 / 1814-0998-2021-3-97-104$

\section{ВВЕДЕНИЕ}

В последние десятилетия обострилось внимание специалистов-гуманитариев к истории низовой, неофициальной, опирающейся на устную коллективную и индивидуальную память и интерпретации. Особый интерес представляют события социальной истории, включающие межэтнические взаимодействия, так как они вскрывают культурно обусловленные модели поведения, следование тем стереотипам, которые длительное время складывались в конкретных исторических обстоятельствах. Наша статья посвящена анализу процесса коллективизации локальной группы вилюнейских чукчей, который сопровождался множественными этнически маркированными эпизодами вооруженного противодействия оленеводов советским преобразованиям, в том числе созданию колхозов. Тема является значимой в свете того, что коллективизация именно этой группы являлась наиболее острой, насыщенной и насильственной, что влечет повышенное эмоциональное восприятие со стороны как непосредственных участников, так и тех, кто получает вторичную, транслируемую различными источниками информацию. До настоящего времени большой резонанс имеет центральное событие коллективизации вилюнейцев, известное как «березовское восстание». Действия, причис-

(C) Хаховская Л. Н., 2021 ляемые к собственно восстанию, развернулись весной 1949 г. в селе Берёзово Марковского района Чукотского национального округа.

Историография данного события противоречива как в части описания фактов, так и в части их интерпретации. Официальная версия, изложенная в работах советского и постсоветского времени, обращает внимание прежде всего на противоправные и насильственные действия оленеводов и постулирует оправданность ответных мер (Гарусов, 1981; Слабука, эл. ресурс). Авторы значительной части современных работ изначально настроены сочувственно по отношению к восставшим, что определяет характер подачи материала (Нувано, 2008; Задорин и др., 2011; Коломиец, Нувано, 2017). В некоторых работах такого плана органам власти приписывается неоправданная жестокость (например, убийство детей при задержании восставших (Ларьков, Романенко, 2010)), что не соответствует действительности.

Терминологически рассматриваемое событие квалифицируется как восстание (мятеж), что отражает его изначальную вписанность в соответствующий политический контекст. Как видно из архивных документов, партийные работники начали называть березовские события восстанием именно «по горячим следам», исходя из сложившегося на тот момент официального дискурса о крестьянских восстаниях против раскулачивания, немногим ранее происходивших в других 
регионах страны. Не случайно в выступлениях лиц советской номенклатуры тех лет березовское восстание сопровождается эпитетом «кулацкое» [Государственный архив Магаданской области (ГАМО), ф. П-22, оп. 1, д. 388, л. 97; ф. П-66, оп. 1 , д. 1 , л. 37 ; и др.]. Советские и постсоветские исследователи этой темы такую квалификацию событий не оспаривали, а пользовались ею как данностью.

Наша работа призвана внести коррективы в эти устоявшиеся представления. Ее целью является восстановление событийной канвы березовского противостояния, показ исторической подоплеки развернувшихся событий, анализ мотивов и стереотипов действий обеих сторон, выявление этнической и социальной составляющих поведения групп людей и отдельных лиц, оказавших решающее влияние на эскалацию конфликта. Источниковой базой нашего исследования, помимо опубликованных работ, служат впервые вводимые в оборот архивные документы из фондов Государственного архива Магаданской области и научного архива Магаданского областного краеведческого музея (НА МОКМ).

Методологической основой работы является подход к межэтническим процессам и взаимодействиям как основанным на устойчивых моделях поведения, которые формируются длительное время в соответствующих исторических условиях. История же определенных локальных сообществ такова, что конфликты и вооруженные столкновения включались в структуру их социальных процессов на протяжении длительного времени, так что они стали не исключительным, а обычным, рядовым явлением. Более того, участие в конфликтах вело к воспроизводству локальной солидарности, укреплению внутреннего общественного порядка, поддержанию соответствующего образа жизни. Роль конфликтов в социальной жизни традиционных обществ исследовал основатель манчестерской антропологической школы М. Глакман. Основываясь на африканском материале, он полагал, что характерной чертой общественного устройства малых этнических сообществ, живущих за счет традиционного природопользования, является постоянное воспроизведение смут и мятежей, которые в этом свете предстают не чрезвычайными, а нормальными перманентными событиями (Gluckman, 2004). В работах М. Глакмана содержится важная идея о том, что антропологам надлежит фокусировать внимание на переменах, на процессах и на конфликтах, а не на стабильности.

Известно, что этническая история кочевых чукчей на протяжении, по меньшей мере, полутора веков включала постоянные столкновения с широким кругом этнических сообществ (ко- ряки, юкагиры, эскимосы, русские). Становление крупностадного чукотского оленеводства и расширение зоны обитания чукчей базировалось на их завоевательных походах, что отмечал Н. Н. Диков: «... распространение Голеневодства] связано здесь с войнами. Захватывая стада у коряков и юкагиров, чукчи расселялись со стороны Чукотского полуострова» (1960. С. 103).

Готовность к конфликту, к вооруженным походам, нацеленным на захват добычи, в значительной мере сформировала общественный строй чукчей-оленеводов и социальные взаимоотношения внутри сообщества. Мы рассматриваем березовскую «смуту» именно в таком социокультурном ключе. Некоторые из авторов также отмечают историческую и этнокультурную подоплеку березовского конфликта, следование традиционным убеждениям и выработанному «кодексу» поведения в острых ситуациях (Слабука, эл. ресурс; Задорин и др., 2011. С. 21, 24). В пользу такого подхода говорит также тот факт, что за много лет до этого среди вилюнейцев имели место другие трагические события, без сомнения, сыгравшие роль своеобразного пролога. Таким образом, березовское противостояние коллективизации состояло из целой цепочки столкновений, а так называемое восстание стало его кульминацией.

\section{ПРОЛОГ: СОБЫТИЯ 1940-х ГОДОВ}

Село Берёзово было основано в самом начале 1930-х гг. как центр оседания созданного в 1932 г. товарищества по выпасу оленей «Имени Ленина». В дальнейшем из ряда малооленных чукотских хозяйств, кочевавших в Марковском районе, организуются еще несколько товариществ, в значительной мере сохранявших независимость от органов власти и традиционный образ жизни.

Летом 1940 г. на Чукотке началась масштабная кампания по переводу товариществ на устав сельскохозяйственной артели (колхоза), а также созданию новых коллективных хозяйств. Наиболее действенным инструментом вовлечения в колхозы являлось взимание с единоличников повышенных ставок налогов (сельскохозяйственный и сбор на нужды жилищного и культурнобытового строительства). С этой целью в тундру были посланы бригады уполномоченных. Как видно из документов, «в результате этой работь от многих кулаков-оленеводов уходили батраки, которые сейчас же вступали в колхозы» [ГАМО, ф. П-22, оп. 1, д. 94, л. 118].

В ходе кампании в Марковском районе из трех маломощных оленеводческих товариществ чукчей («Имени Ленина», «Вилюнейское», «Полярная звезда») и некоторых оленеводов-единоличников сформировали колхоз «Полярная звезда» с центральной усадьбой в Берёзово. В колхозе насчитывались 29 хо- 
зяйств, 222 человека (из них трудоспособных 141), которые обобществили 182 оленя. В личной собственности колхозников имелся 2251 олень, или 77 голов на семью. Отсутствие подсобных отраслей и крайняя малооленность привели к тяжелому положению: «колхозники вынуждены питаться и существовать только за счет оленей, ... вынуждены забивать личных оленей, ... колхозники находятся в полуголодном существовании» [ГАМО, ф. П-22, оп. 1, д. 213 , лл. 40, 41]. Таким образом, ставка на «бедняков и батраков», которые захотели освободиться от зависимости от своих хозяев, привела к изначальной экономической несостоятельности вновь образованного оленеводческого колхоза.

Вместе с тем, как видно из архивных документов, органы советской власти и чукотские активисты предпринимали усилия по укреплению колхоза и помощи его членам. Как вспоминает председатель Березовского сельсовета, чукча Григорий Улянго, «чем больше становилось стойбище, тем привоз продуктов улучшался, так как больше стало ездовых оленей. Стали умело распределять рабочую силу: одних отправляли за товарами, других - в стадо, третьих на охоту. <..> ... наше хозяйство крепло, больше стали привозить продуктов. И кулаки стали приезжать в колхоз, чтобы закупить товары» [НА МОКМ, д. 72, лл. 7, 8].

На территории Марковского района выпасали свои стада также зажиточные оленеводыединоличники, известные как локальная группа вилюнейских чукчей. Лидером группы в конце 1930-х гг. стал крупный оленевод Гемауге (в другом написании Гемавье, Гимавье). Вилюнейцы уклонялись от коллективизации, периодически укочевывая в труднодоступные места Анадырского района и сопредельного Корякского округа. В феврале 1941 г. для работы среди вилюнейских чукчей в тундру выехала группа в составе уполномоченного Николая Ивановича Майлина (собирал налоги, проводил коллективизацию), 30отехника совхоза «Снежное» Екимова (закупал оленей и набирал пастухов для совхоза), переводчика Филиппа Дьячкова и каюра Афанасия Павлова (местные жители, камчадал и эвен). В стойбище вилюнейца Кававто в качестве проводника был нанят чукча (по другим сведениям, коряк) Эйнелькут (Айнелькут), бывший член товарищества «Корякское», в 1939 г. вошедшего в колхоз «Светлая жизнь» (с. Ваеги Марковского района). Эйнелькут в этот колхоз не вступил, он обладал только ездовыми оленями и занимался охотой. Есть сведения, что Майлин стал требовать с Эйнелькута, как единоличника, внести налог в виде нескольких оленей. Одновременно Екимов вербовал его, как безоленного, пастухом в совхоз. Эйнелькут согласился работать в совхозе и, в свою очередь, предложил услуги проводника до следующего стойбища [ГАМО, ф. П-22, оп. 1, д. 93, л. 34; ф. П-28, оп. 3 , д. 31 , лл. 7,16$]$.

Однако, как показали дальнейшие события, готовность Эйнелькута помогать советским сотрудникам была притворной. Пользуясь доверием своих спутников, которые даже не были вооружены, в одну из ночей 19-21 февраля 1941 г. [ГАМО, ф. П-28, оп. 3, д. 31, л. 4] ${ }^{1}$ Эйнелькут застрелил из винчестера всех четверых спящими, а трупы спрятал (по одной из версий, сбросил в реку (Гарусов, 1981. С. 131), по другой - зарыл в снег (устное сообщение В. Н. Нувано от 04.03.2020)). Затем он скрылся в стойбище Гемауге, которое немедленно откочевало в неизвестном направлении. Тела убитых нашли лишь в конце апреля. Дьячкова и Павлова захоронили в с. Ваеги, Майлина и Екимова - в с. Марково.

Группа оперативных работников выследила и настигла Эйнелькута в том же стойбище спустя год. Вместе с ним были захвачены и вывезены в Анадырь Гемауге и Уттель (Утын), считавшиеся подстрекателями убийства [ГАМО, ф. П-22, оп. 1, д. 388, л. 98]. Задержание сопровождалось перестрелкой, в ходе которой со стороны оленеводов, по-видимому, был убит один из сыновей Гемауге - Котаквургин. В этой акции проявилось характерное поведение чукчей, пытавшихся доступными им, порой весьма наивными способами спрятать и отстоять своих родственников. При этом в число противников включались не только представители других этнических групп, но и соплеменники, если они стали «красными».

Участник события чукча Улянго воспоминает: «Здесь уже было много яранг (около 30). Зашли в одну ярангу, а там собрались известные мне отчаянные кулаки... я быстро сообразил и пробрался в полог и нашел здесь запрятанного кулака, он был сильный, кое-как выволок его из полога и привязал к нарте ... пошел в большую ярангу, чтобы расправиться с главным кулаком. На мой вопрос: «Где Гемауге»? - получил ответ: "Он уехал в далекое стойбище». <...> Помню, одной рукой приподнял край полога, другой шарю внутри него. Кулак так закутался в меховую одежду (с ног до головы), а сверху ещзе накрыт шкурой. ... нашупал его и выташчи в ярангу...Когда стал помогать его выносить, не заметил, что у двери сидит женщина. ... она взяла палку и сильно ударила меня сзади по голове. Я ... потерял сознание и тут же упал... Поднялась суматоха, двух кулаков убили, они рвались к яранге» [НА МОКМ, д. 72, лл. 8, 9].

${ }^{1} \mathrm{~B}$ ряде публикаций это событие ошибочно датируется 1940 годом (Гарусов, 1981. С. 131; Нувано, 2008. С. 85, 86; Омрытхэут, 2008. С. 91; Коломиец, Нувано, 2017. С. 81). 
В Анадыре Эйнелькут, Гемауге и Уттель были расстреляны по приговору суда [ГАМО, ф. П-22, оп. 1, д. 423 , л. 29$]^{2}$. Руководство вилюнейской группой перешло к двум сыновьям Гемауге Трунко и Экетэту.

Агрессию Эйнелькута одинаково негативно оценивают авторы, придерживающиеся разных точек зрения на чукотскую коллективизацию (Гарусов, 1981. С. 131; Нувано, 2008. С. 87), однако мотивы его действий не объяснены. Судя по всему, Эйнелькут, как и другие обитатели стойбища, в котором он находился, в свое время дали согласие объединиться в коллективное хозяйство, о чем были составлены документы. На этом основании они пытались возражать против повышенного налога, взимаемого группой Майлина. Майлин, в свою очередь, запросил районные власти проверить этот факт и получил отрицательный ответ: документы о создании колхоза не нашлись (они были обнаружены только спустя много времени после трагедии). Поэтому он все же выдал предписание об уплате налога обитателям стойбища и тем самым подписал смертный приговор своей группе. Эйнелькут, как и другие чукчи, возможно, искренне считали себя колхозниками и потому не хотели мириться с предписанием. Чувство несправедливости, отсутствие легальных способов доказать свою правоту толкнуло Эйнелькута на экстремальные действия, замаскированные предложением помощи.

Особую остроту происходящему, безусловно, придавали резкие сдвиги этносоциального плана. Не имея достаточного количества оленей, Эйнелькут подрядился работать простым пастухом. Это была обычная практика чукчей и коряков в собственной этнической среде, единственно возможный выход для малооленного хозяина в традиционном обществе. Однако данное событие произошло в качественно иных обстоятельствах: собственниками стада становились не соплеменники, а пришлые люди, обобщенно воспринимаемые как «русские». По всей вероятности, Эйнелькут испытывал чувство унижения, изъятие оленей для него стало болезненным событием, осложненным тем, что теперь ему предложили пасти оленей «у русских». В этом свете действия Эйнелькута объясняются осознанной местью за поруганное «пришельцами» достоинство. Весьма вероятно, что это был заранее обдуманный и согласованный с вилюнейскими чукчами план [ГАМО, ф. П-28, оп. 3 , д. 31 , лл. 23, 30, 30об.].

Осознание социально-экономического ущемления, связываемого с различающейся этнической идентичностью, в среде захваченных опи-

${ }^{2}$ Существует ошибочная версия, что Гемауге покончил с собой (Коломиец, Нувано, 2017. С. 81). санными событиями вилюнейцев продолжало сохраняться и подпитывать их сопротивление органам советской власти. Это видно, например, из тех умонастроений, которые царили в стойбище оленевода Трунко и его соседей. После ареста Гемауге было принято решение о конфискации его стада (3.5 тыс. голов). Однако Трунко, считая себя законным наследником, отдавать оленей отказался, заявив: «Этот табун мой, вам, русским, там делать нечего» [ГАМО, ф. П-22, оп. 1, д. 180 , л. 2].

Зимой 1943 г. стойбище Трунко, кочевавшее в верховьях р. Хатырка, посетила группа уполномоченных для проведения подписки на денежновещевую лотерею, сбора теплой одежды для бойцов Красной Армии, инвентаризации оленей. Однако, как видно из документов, «стойбище Трунко категорически отказалось помогать нашей родине. Собрание стойбища продолжалось три дня, на третий день, 10 декабря 1943 г., на собрании выступил кулак Трунко с заявлением "Выполнять советские законын не будем, мы готовы в любую минуту дать отпор русским, если кто из нас погибнет, то и ваших немало будет уничтожено. < .. > C сегодняшнего дня объявляю войну против русских. Как видно, мне сейчас дорога к отиу. Может, мне осталось недолго здесь быть, но я буду делать так, как делал мой отец. Советской власти подчиняться не буду"» [Там же].

Воинственный дух Трунко разделяли не только члены его стойбища (18 яранг, 40-50 человек, владевших 17 ружьями), но и другие вилюнейские оленеводы, кочевавшие в радиусе 6080 км [Там же]. Столкновение в тот год не произошло из-за временного отказа властей от давления на единоличников, но конфликт не угас. Трунко умер в 1944 г., Экетэт погиб при вооруженной стычке с органами власти в 1946 г. ${ }^{3}$ Вилюнейскую группу возглавили чукчи Кутынкеу, Анявкай и Мыргымыр [ГАМО, ф. П-22, оп. 1, д. 388, л. 98].

Таким образом, на протяжении, по меньшей мере, десятилетия, вилюнейцы жили с постоянным ощущением враждебного окружения и готовностью дать отпор. Этот менталитет очень точно передал эссеист И. Омрувье, вложив в уста своего героя, вилюнейского оленевода Маравье, такие слова: «Сначала наисовет, потом культбаза, и, наконеи, Красная яранга, эти товарищества и еще какой-то комсомол... Все они сообща, вместе стараются накинуть на меня, на наши шеи аркан. Словно иелая стая голодных волков за нами постоянно следит!» (2017. С. 47). Такой

${ }^{3}$ Одновременно были арестованы оленеводы Какы и Ранаквургин, в то время как ряд источников ошибочно считают последнего участником березовских событий (Задорин и др., 2011. С. 25, 26). 
мобилизационный настрой, по нашему мнению, являлся типичным для общества так называемой военной демократии, сформировавшегося у чукчей в ходе завоевательных походов и становления крупностадного оленеводства.

\section{БЕРЕЗОВСКАЯ «СМУТА»: СОБЫТИЯ 1949 ГОДА}

В конце 1940-х гг. «наступление на кулака» на Чукотке возобновилось. Единоличников вынуждали вступать в колхозы разными мерами, в том числе проверенным методом обложения повышенными налогами. В итоге основная масса чукотских оленеводов была коллективизирована. Одновременно росла и социальная напряженность: «Сельхозналог является самым трудным мероприятием в глубинной тундре. Часть кочевников дают категорический отказ по уплате сельхозналога и скрываются от проводимых работников, а иаманы и кулаки ведут соответствуюшую работу, чтобы все отказывались от налога. До сих пор среди оленеводов, кулаков, шаманов и части бедняков не изжито проамериканское настроение» [ГАМО, ф. П-22, оп. 1, д. 393, л. 21об.].

В конце 1947 г. в колхоз «Полярная звезда» вступила группа вилюнейских чукчей, в том числе такие крупные оленеводы, как Кутынкеу, Келеуги, Келевье, Анявкай [ГАМО, ф. П-22, оп. 1, д. 368 , л. 23; д. 337, л. 88]. Обобществленные олени этих «новых» колхозников пополнили общественное стадо, в результате доходы колхоза возросли, так как увеличилось ежегодное количество продаваемых на сторону оленей (с 250 до 5 тыс. голов). Коллективизация единоличников стала одним из факторов, благодаря которому Марковский район выполнил четвертый пятилетний план по оленеводству за три года. Тем не менее финансовое положение колхоза «Полярная звезда» было слабым, поскольку предприятия не спешили расплачиваться за купленных оленей, соответственно колхоз не мог оплатить труд оленеводов [ГАМО, ф. П-28, оп. 2, д. 37, л. 7]. «Новые» колхозники-вилюнейцы были поставлены в крайне стесненные жизненные условия. Есть сведения, что они находились на вторых ролях по сравнению со «старыми» колхозниками, им в последнюю очередь начисляли трудодни и оплачивали их [ГАМО, ф. П-66, оп. 1, д. 1, лл. 9, 11]. В противовес этому существует мнение, что вновь вступившие оленеводы сами уклонялись от общественной работы и потому не имели трудодней (Слабука, эл. ресурс).

Ситуацию в колхозе сильно осложнял жесткий, авторитарный стиль работы председателя, чуванца Александра Алина, которого описывают как человека грубого, малообразованного, не обладавшего организаторскими способностями
(Задорин и др., 2011. С. 21). В негативной оценке Алина сходятся официальные и неформальные источники. Как следует из документов, он запугивал вилюнейцев, не считался с их мнением по хозяйственным вопросам, заставлял их говорить по-русски [ГАМО, ф. П-66, оп. 1, д. 1, лл. 9-11]. По воспоминаниям местных жителей, «этот человек нехороший был к тем, кто не понимал русский язык» (Нувано, 2008. С. 88); «В то время начальником колхоза был очень плохой человек. $<\ldots>$ Трудодни рыбаков и оленеводов он начислял себе... Голодал очень народ. Поэтому и возмутился ...» (Омрытхэут, 2008. С. 94).

Правление колхоза, стремясь достичь высоких показателей, постоянно изымало личных оленей у новых колхозников. Так, у Кутынкеу в 19481949 гг. трижды изымали оленей, нанося ему не только имущественный, но и социальный ущерб [ГАМО, ф. П-28, оп. 2, д. 37, л. 7]. Партийные руководители района были осведомлены о неблагополучном положении колхозников и жестком руководстве, однако закрывали на это глаза [ГАМО, ф. П-22, оп. 1, д. 368, л. 23].

Особое возмущение вилюнейцев вызвал запрет забивать оленей при проведении традиционного праздника рогов «килвэй» весной 1949 г. В предыдущий год председатель Березовского сельсовета Улянго, понимая важность этой традиции, позволил провести забой, за что получил выговор от вышестоящих органов. Улянго поэтому самоустранился, а решение принял председатель Алин. Однако даже это возмущение не привело к «смуте». Непосредственным поводом к конфликту стало внешнее влияние на колхозников-вилюнейцев.

Зимой 1949 г. в окрестности села Берёзово прикочевала группа вилюнейских чукчейединоличников, в числе которых были «богатые оленные люди» Антолин, Тыневентын, Эйневтегин, Мыргымыр, Пеляургын. Они стали уговаривать колхозников-вилюнейцев укочевать с ними в тундру (Шарыпова, эл. ресурс). Единоличники обладали большим количеством винчестеров и патронов американского производства, в том числе новыми [ГАМО, ф. П-22, оп. 1, д. 388, л. 99]. Существует версия, что вооруженное выступление вилюнейцев было подготовлено спецслужбами США (Слабука, эл. ресурс), однако нам это кажется маловероятным. Истинная причина «откалывания» сородичей от колхоза заключалась в том, что богатые стадами единоличники нуждались в рабочей силе. Нехватка пастухов у крупных оленеводов-вилюнейцев стала ведущим фактором их поведения, что отмечено и в художественной прозе (Омрувье, 2017. С. 47). В период становления чукотского оленеводства «кадры» пастухов в значительной мере формировались из захваченных в плен ко- 
рякских детей и подростков, а затем - из обедневших сородичей, однако вследствие советских преобразований последний источник все более иссякал [ГАМО, ф. П-22, оп. 1, д. 388, л. 100].

Вторым значимым фактором березовского выступления стала убежденность вилюнейцев в том, что они смогут скрыться, откочевать на территории, не охваченные коллективизацией, в качестве которых они рассматривали территорию соседнего Корякского округа. Среди оленеводов, несомненно, циркулировало представление о том, что существуют местности, недосягаемые для представителей советской власти. В пользу этого говорила их предшествующая многолетняя практика, основанная, в свою очередь, на традиционной модели поведения: после конфликта, сопряженного с захватом добычи, уйти в безопасное место. Эта память о былой вольнице, о существовании заповедных, недоступных для противника мест, в значительной мере стимулировала «восстание», которое по своей первоначальной сути, обусловленной намерениями «повстанцев», также заключалось в обеспечении себя всем необходимым для дальней кочевки.

У единоличников, судя по всему, существовал план, выработанный такими лидерами, как Нотай, Айван, Мыргымыр, Айнявкай (брат Кутынкеу). План состоял в нападении на колхозные обозы с целью захватить оленьи нарты и продукты, а также отогнать часть колхозного стада - тех обобществленных животных, которые вилюнейцы продолжали считать своими. По некоторым данным, они собирались также напасть на Берёзово, чтобы «перебить русских» (Слабука, эл. ресурс). Однако более вероятно, что описанная ниже стычка в селе стала следствием уже развернувшегося противостояния с этносоциальной подоплекой.

В один из дней начала марта 1949 г. группа чукчей, во главе с Нотаем и Тынэвом, остановила два колхозных обоза (аргиша), численностью 130-200 нарт. Один обоз направлялся из Берёзово в Марково, он вез мясо, рыбу и меховое сырье, другой двигался в обратном направлении, на нем везли продукты (сахар, масло, муку) и промтовары. Бригадирами обозов были Кеныр и Ятгыргин, каюрами - женщины. Согласно воспоминаниям самого Ятгыргина, ему «пригрозили, что если не соглашусь вернуть аргиш в Берёзово, то меня и женшчин расстреляют» (Задорин и др., 2011. С. 26). В результате вилюнейцы захватили все нарты и часть груза, остальную поклажу сбросили на снег. Нарты отвели в свои стойбища вблизи села.

Березовские активисты не остались безучастными к этой акции, нанесшей большой ущерб колхозу. Кроме того, у них были основания опасаться нападения единоличников непосредственно на село. Они решили действовать на упреждение: «Актив села, состоявший из председателя сельсовета Улянго, радиста Анатолия Уварова, учителя начальных классов Николая Забалуева, директора школь Ивтека Березкина и других, выдвинулся к ярангам мятежников» (Слабука, эл. ресурс). Они арестовали 8 зачинщиков, вернули основную часть колхозного добра, организовали охрану села. Стычка сопровождалась перестрелкой, среди вилюнейцев были убитые и раненые (Кергинайвын, Этынкеу, Кенуп) (Задорин и др., 2011. С. 25, 26). Некоторые источники ошибочно приписывают этот эпизод финальному событию березовского противостояния - задержанию кочевников в вилюнейской тундре 4 (Там же. С. 23).

«Мятежники», в свою очередь, предприняли нападение на село, чтобы освободить сородичей, отбить нарты и груз, увести оленей. Вооруженная группа чукчей до 30 человек утром 15 марта ворвалась в село. Они избили продавца Николая Евтюшкина, учителя Забалуева, ранили Улянго и убили члена правления колхоза Айняу. В ходе перестрелки появились жертвы и среди нападавших. К ним присоединились колхозники с семьями, всего почти 100 человек. Вся эта группа, отогнав также колхозных и личных оленей, начала спешно кочевать в вилюнейскую тундру.

Однако расчеты вилюнейских оленеводов скрыться в глубинной тундре не оправдались. По их следам на собачьих упряжках выступила оперативная группа из 32 человек, которая спустя месяц настигла бежавших в 200 км от села. Задержание произошло практически бескровно, путем переговоров и тактических маневров. Многие из чукчей были сильно напуганы произошедшим накануне групповым самоубийством: лидеры группы Нотай и Айван, узнав о преследовании, застрелили своих жен и детей, а затем покончили с собой. Кровавая картина в одном из жилищ потрясла оперативников: «посреди яранги лежал Нотай, рядом его жена прижимала к груди трупик 5-месячного младения. Возле нее находилась 4-летняя дочь выстрелом из винчестера отеи снес ей половину головы» (Слабука, эл. ресурс). Есть сведения, что такая же судьба постигла семьи чукчей Тэнутылина, Лялио (Задорин и др., 2011. С. 24) и Тенкылина (Омрытхэут, 2008. С. 94).

${ }^{4}$ Для воспоминаний очевидцев вообще характерно смещение событий во времени - эпизоды достаточно длительного, разнесенного во времени березовского конфликта спрессованы и подтянуты к центральному акту задержания вилюнейцев в середине апреля 1949 г. (Задорин и др., 2011. С. 23, 24, 26). 
Следует отметить, что данная акция полностью соответствовала чукотским традициям и сопровождалась принесением в жертву ездовых оленей для путешествия в мир мертвых (Задорин и др., 2011. С. 20, 21, 24). Групповые семейные самоубийства среди чукчей и коряков в условиях вооруженных столкновений, чреватых угрозой пленения, многократно отмечены источниками периода освоения русскими Крайнего СевероВостока (Зуев, 2009. С. 310, 311). Таким образом, эскалация современного социального конфликта, сопровождавшаяся насилием с обеих сторон, завершилась воспроизведением тех обычаев, которые были закреплены длительной историей ожесточенных межэтнических противостояний.

По результатам следствия из вилюнейских кочевников к тюремному заключению были приговорены, по имеющимся данным, до 20 человек (Задорин и др., 2011. С. 26). Согласно воспоминаниям, восемь человек вернулись, отбыв различные сроки (от 6 до 9 лет) - Кутынкеу, Келевье, Коольгин, Ятгыргин, Мыргымыр, Кеныр (Кена?), Коравье, Тыневентын); четверо умерли в Анадырской тюрьме (Танно (Таньо), Татит (Татат), Ира, Ивтэгрет (Итэвгрет)), в Хабаровской тюрьме скончался Келевье, в неизвестной тюрьме - Онэнэ (Нувано, 2008. С. 85-94). Айнявкай, по одной версии, был убит, по другой - отсидел срок и вернулся домой (Омрытхэут, 2008. С. 93, 94). Неизвестна судьба арестованных Кергинто, Тынэва, Гиувье.

После березовских событий колхоз возобновил обычную работу, но они не могли не сказаться на моральном настрое колхозников. В это время на Чукотке началась кампания по укрупнению хозяйств и населенных пунктов, что решило участь березовцев. В 1951 г. «Полярную звезду» объединили с ваежским хозяйством «Светлая жизнь». Новый колхоз назвали «Путь к коммунизму», его центральной усадьбой стало село Ваеги. Жителей Берёзово переселили в села Ваеги, Хатырка и Марково.

\section{ЗАКЛЮЧЕНИЕ}

Так называемое березовское восстание было вызвано противостоянием между руководителем колхоза, местными активистами, «старыми» колхозниками, недавно вошедшими в колхоз вилюнейцами и вилюнейской группой оленеводовединоличников. Генезис конфликта имел этносоциальную природу, так как перераспределение властных полномочий и хозяйственных компетенций у кочевников происходило не в рамках собственного локального сообщества, а в новой полиэтничной среде. Вилюнейцы-колхозники были лишены целого ряда возможностей управлять своей жизнью, находились в зависимости от колхозного и советского актива, представители которого не смогли за почти двухлетний период выстроить с ними такие же взаимоприемлемые отношения, как со «старыми», изначально коллективизированными оленеводами. В свою очередь, вилюнейцы-единоличники, обладая крупными стадами, нуждались в пастухах, для чего предприняли попытку отколоть своих сородичей от колхоза и откочевать в недоступную для советской власти местность. В результате не прижившиеся в полиэтничном колхозе оленеводы склонились на сторону соплеменников.

Березовские события не являлись восстанием ни по своей сути (масштабу и целям), ни по генезису. Данная акция была локальной, затронула ограниченный круг участников, поведение которых характеризуется как спонтанное, неорганизованное. У выступавших отсутствовал четкий план, согласованность их действий была слабой. Вилюнейцы стремились не свергнуть установившийся властный порядок, а ускользнуть от него. Именно поэтому осознание безвыходности положения привело к трагической развязке, которая базировалась на стойком убеждении предпочесть смерть плену.

В целом в событиях коллективизации 1940-х гг. данное локальное сообщество руководствовалось теми стереотипами межэтнических взаимодействий, которые сложились в предшествующую историческую эпоху, когда противостояния и конфликты являлись событиями повторяющимися, а не исключительными. Модели поведения, закрепленные предшествующим этнокультурным развитием, были воспроизведены в сходных обстоятельствах, что и послужило глубинной причиной эскалации березовского конфликта.

\section{ЛИТЕРАТУРА}

Гарусов И. С. Социалистическое переустройство сельского и промыслового хозяйства Чукотки (19171952 гг.). Магадан : Кн. изд-во, 1981. 190 с.

Диков Н. Н. По следам древних костров. Магадан : Кн. изд-во, 1960. 104 с.

Задорин В., Омрувье И., Шарыпова А. Коллективизация по-чукотски // Мир Севера. 2011. № 1. С. 20-27.

Зуев А. С. Присоединение Чукотки к России (вторая половина XVII - XVIII век). Новосибирск : Изд-во CO PAH, 2009. $444 \mathrm{c}$.

Коломиец О. П., Нувано В. Н. Чукотское оленеводство в конце XIX - первой половине XX в. // Томский журнал лингвистических и антропологических исследований. 2017. № 4. С. 76-88.

Ларьков С. А., Романенко Ф. А. «Враги народа» за Полярным кругом. Москва : Paulsen, 2010. 432 с.

Нувано В. Н. Трагедия в селах Березово и Ваеги: 1940, 1949 // Тропою Богораза. Научные и литературные материалы. Москва : Институт Наследия - ГЕОС, 2008. C. 85-91.

Омрувье И. Вилюнейский репортаж // Мир Севера. 2017. № 5. С. 41-68. 
Омрытхэут 3. Г. Эхо Березовского восстания. Очевидцы о событиях 1940 и 1949 гг. // Тропою Богораза. Научные и литературные материалы. Москва : Институт Наследия - ГЕОС, 2008. С. 9194.

Слабука Д. Законы северного «гостеприимства» [Электрон. pecypc]. URL: https://web.archive.org/ web/20140425024207/http://www.svrpu.ru/psv/ 4056/301545.php

Шарыпова А. У первого камня на Майне стоит молодое село... [Электрон. ресурc]. URL: http://www. ks87.ru/21/2759.html

Gluckman M. Order and Rebellion in Tribal Africa. London and New York : Routledge, 2004. 273 p.

Поступила в редакиию 18.06.2021 2.

Поступила после доработки 11.08.2021 2.

\section{COLLECTIVIZATION OF VILYUNEY CHUKCHI : THE REASONS FOR AND THE COURSE OF THE CONFRONTATION}

\section{N. Khakhovskaya}

North-East Interdisciplinary Scientific Research Institute n. a. N. A. Shilo, FEB RAS, Magadan

The author analyzes the process of collectivization of the Vilyuney Chukchi local group. Chukchi reindeer herders put up armed resistance to Soviet reforms. The central event of the Vilyuney Chukchi collectivization, known as the Beryozovo village riot, has a great resonance. The author traces the historical, social, and ethnocultural background of the Vilyuney Chukchi long-term opposition to the Soviet power. The conclusion is that during collectivization the Vilyuney Chukchi were following the ethnic interaction stereotypes developed in the previous historical period.

\section{Keywords: Chukchi, Vilyuney tundra, collectivization, ethnosocial conflict, ethnic history,} Beryozovo village, armed struggle.

\section{REFERENCES}

Dikov, N. N., 1960. Following the Footsteps of Ancient Bonfires. Magadan [In Russian].

Garusov, I. S., 1981. Socialist Reorganization of Chukotka's Agriculture and Trade Economy (1917-1952). Magadan [In Russian].

Gluckman, M., 2004. Order and Rebellion in Tribal Africa. London and New York, Routledge.

Kolomiets, O. P., Nuvano, V. N., 2017. Chukchi Reindeer Breeding in the Late $19^{\text {th }}-$ the First Half of the $20^{\text {th }}$ Century, Tomsk Journal of Linguistics and Anthropology. 4, 76-88 [In Russian].

Larkov, S. A., Romanenko, F. A., 2010. "Enemies of the People" in the Arctic Circle. Moscow, Paulsen [In Russian].

Nuvano, $V . N$. , 2008. Tragedies in the Villages of Beryozovo and Vaegy. 1940 and 1949, By the Path of Bogoraz. Research and Literary Materials. Moscow, Russian Heritage Institute - GEOS. 85-91 [In Russian].
Omruvye I., 2017. Reportage of the Vilyuney, World of the North. 5, 41-68 [In Russian].

Omrytkheut, Z. G., 2008. Beryozovo Riot Echo. Testimonies of 1940 and 1949, By the Path of Bogoraz. Research and Literary Materials. Moscow, Russian Heritage Institute - GEOS. 91-94 [In Russian].

Sharypova, A., 2011. The Young Village Stands at the First Stone on the Mine... [Electronic Resource]. URL: http://www.ks87.ru/21/2759.html [In Russian].

Slabuka D. Northern "Hosptality" Laws [Electronic Resource]. URL: https://web.archive.org/web/201404250 24207, http://www.svrpu.ru/psv/4056/301545.php [In Russian].

Zadorin, V., Omruvye, I., Sharypova, A., 2011. Collectivization: Chukchi Way, Mir Severa. 1, 20-27 [In Russian].

Zuyev, A. S., 2009. Incorporating Chukotka to Russia (Second Half of the $17^{\text {th }}-18^{\text {th }}$ Centuries). Novosibirsk, SB RAN [In Russian]. 